\title{
MIMacrothink

\section{An Empirical Study of Industrial Conflict and Management in Nigeria Local Government System: A study of Enugu State}

\author{
Emma E.O. Chukwuemeka, Ph.D \\ Senior Lecturer, Public Administration/Coordinator, Postgraduate Studies \\ Faculty of Management Sciences, Nnamdi Azikiwe University, Awka Nigeria. \\ P.M.B. 5025, Awka.. e mail hrvkonsult@yahoo.com \\ Tel: 08060967169; 08052671039 \\ Joy Ugwu, Ph.D \\ Director, School of Business Studies, \\ Institute of Management and Technology, Enugu, Nigeria \\ Titus Okey Enugu, Ph.D \\ Senior Lecturer, Department of Business Administration \\ Enugu State University of Science and Technology, Enugu, Nigeria \\ Dan Igwegbe \\ Akanu Ibiam Federal Polytechnic Unwana, Afikpo, Nigeria \\ Accepted: May 17, 2012 Published: July 04, 2012 \\ Doi:10.5296/ijhrs.v2i3.2048ＵRL: http://dx.doi.org/10.5296/ijhrs.v2i3.2048
}

\begin{abstract}
The study was carried out to assess labout conflict and management in the local Government system in Nigeria with particular reference to Enugu State. Descriptive Research method was adopted, data were collected and analysed. Essentially, the findings revealed that the organizational framework for management of conflict and grievances is poor. The problem is as a result of leadership ineffectiveness which according to the study had resulted to disputes and consequently to strike actions. Management scarcely bargains with staff in resolving conflict situations. Management does not always explain its reasons for taking a particular position in resolving conflicts. The study further revealed that other factors that heightened labour conflict include low participation of employees in taking key decisions, especially matters affecting them. The Local overnment of Enugu State of Nigeria is believed to be poorly funded, This information was furnished by a key respondent, the poor funding is peculiar to the following local governments: Enugu North, Igbo-Eze North, and Nsukka Local Government Areas.. The aforementioned local government areas were consistently on 'zero allocation', which the resultant effect was epileptic payment of salaries and allowances of workers. Flowing from the findings, the following recommendations among others were proffered A democratic leadership style should be imbibed in Enugu State Local Government
\end{abstract}




\section{M| Macrothink

Councils to ensure congenial work relationship, the reign of democracy, as a style would ensure reduction of labour conflict. In spite of the fact that funding was not identified as a major problem that led to labour conflict, funding of the Local government in Nigeria should be strengthened. Management and staff of the local government should strive to see labour conflict as a process to change and thus try to resolve it in such a way that both parties are winners. Labour conflict should be resolved through the instrumentality of collective bargaining, which involves negotiation, dialogue, or mediation by a third party or through statutory framework which involves Trade Dispute ACT No.7 of 1976 as amended in 1977.

Keywords: Labour Conflict, Leadership, Funding of Local Government, Collective Bargaining

\section{Introduction}

Government interest in regulating job relations in Nigeria dates back to colonial period with the passing of the Trade Union Ordinance of 1938 by the colonialists and the Trade Dispute (Inquiry and Arbitration) Decree of 1941 (Akpala, 1984). According to Chukwu, (2008) the state is the highest regulator of employment concerning trade unions and their recognition with employers and the relationship between the employer and the unions in the collective bargaining.

There is a tripartite employment relationship among the state, the union and the employer in making and enforcing job rules. The relationship presupposes a congenial and equal participation in issues affecting any of the parties.

Therefore, good industrial relation management is vital to the productivity of workers in organization, considering that management has been defined as the process of combining and utilizing or allocating an organizations inputs (man, materials and money) for planning, organizing, directing and controlling to the purpose of providing goods and services or whatever the objectives (Aka, 2009).

Poor management is bound to occur in an organization with inappropriate or wrong industrial relations management within the organization's framework. Therefore, employers should involve in industrial relations in determining vital issues that affect workers, such as their working conditions, settlement of disputes as they arise, as they are likely to make workers to feel accepted, thereby enhancing productivity in the organization. Again, industrial relation is machinery used by both the employers of labour and employees to reach a compromise for job value, wages, salaries and increase in productivity of employees. To enhance productivity of workers as regards industrial relations management, industrial relations officials are elected by the employees to represent them, although at times, the employers of labour are also involved in appointing officials of such unions. In such cases, the interest of the employers is safe-guarded, and the activities of the union are controlled by the employers of labour. Industrial relations management not only enhances productivity of the workers, but it also helps in settling disputes through collective bargaining, in the areas of job satisfaction, job regulation and job rules (Donkor, 2010). 


\section{M| Macrothink

The great strike of 1945 was a watershed in labour management relations in Nigeria (Ejiofor and Aniagoh, 1984). Several days have been lost to strikes, lockouts, sit-ins, picketing, suspension and dismissals since the colonial era to present day (Eze, 2007).

From the colonial days labour conflict and strike have become a regular occurrence, not only in the local government system, but in other sectors of the Nigerian Economy. For instance, strike actions moved from 30 cases in 1956/57 to 49 cases in 1957/58 and further to 53 in 1958/59 with corresponding increase in loss of resources (Imaga, 1990). Disputes between 1955/56 and 1958/59 led to the loss of a total of 974, 095 days to strike in Nigeria (Demachi, 2009). Between 1990 and 2010, a total of 38,221,761 days were lost to strikes involving 756, 394 workers, including the Nigerian Union of Local Government Employees - NULGE (Imaga, 1990). Between January and May, 2009, a total of 21,439,759 days were lost by the strikes of 259, 039 workers; Ninety-one trade disputes occurred of which $64 \%$ resulted in strikes (Ugo, 2011).

Akereke (2010) contends that from 2003 to 2006, millions of days were lost to strikes by workers of the Local Government Councils across Nigeria over conditions of service. These revelations indicated an increase in the dimensions of labour management conflict.

\section{Statement of Problem}

One of the most fundamental problems currently destabilizing the survival of Nigerian Local Government System is the issue of labour conflict and management. Ezema (2007) argues that most of the Local Government workers are very often restless and confrontational in their approach to issues which affect them as a group, such as the government not fulfilling some of the employment contracts between it and the workers. As a result, they adopt anti-government posture which if care is not taken can tear the state apart.

The government of Nigeria always perceive the workers as lazy, uncooperative individuals, who always hold secret labour meetings and plan drastic actions against government, as well as any organization they consider a threat to the labour interest, while the workers in turn perceive the government as exploiting them (Chukwu 2008). It is this perceptual basis arising from the government and the workers that sometimes serve as the "brewing pot" of the conflict (Halimatu, 2002). Thus, the Local Government has turned to a breeding ground for conflicts. The problem has been compounded by the "zero allocation syndrome" which eventually led to a strike action in the year 2001. The strike involved all the arms of the Nigerian Union of Local Government Employees (NULGE), especially in the Southern part of the country. The nation lost a great deal in terms of financial and material resources (Akereke, 2010).

Ejiofor (1989), argues that many practitioners have erroneously emphasized the role of management at the expense of labour and management. Also crucial is the attitude of government to labour. Government interventions in the field of industrial democracy are not usually explained properly to the half educated and unskilled labour. This has always resulted in spontaneous and unguided attack of almost all management decisions and policies as they relate to labour management relations, within the industrial environment. Government has always made polices concerning labour without labour's consultation. Wages and salaries are fixed by fiat, this according to Chukwuemeka (2011) 
has always led to dispute. In a bid to fight for right of labour, many labour leaders have been jailed. At extreme points, the labour leaders were replaced with sole administrators appointed by government (Nwabuzor, 1990).

The paradox thesis that despite the numerous judicial commissions and reforms recommendations and countless government white papers on Nigeria Local Government System, the problem of labour- management conflict has remained intractable and no meaningful progress has been made. In short, the problem is much more confounding than meet the eye, particularly when one realizes that the aims of creating the local government system in Nigeria are yet to be attained in most parts of the country, especially in Enugu State.

\section{Objectives of the Study}

The general objective of this study is to examine the indices of labour conflict in Nigerian local government system with emphasis in Enugu State. The specific objectives of the study are therefore:

1. To examine the relationship between the nature of management leadership approach and the degree of labour conflict.

2. To examine the correlation between trade dispute and strike.

3. To determine the extent to which "zero" allocation contributed to the endemic labour unrest in the Nigerian local Government system especially in Enugu State.

\section{Hypotheses}

(1) There is no correlation between trade dispute and strike

(2) Labour conflict is independent of leadership style

\section{Literature Review}

\section{Labour Conflict: An overview}

Conflict in broad terms has so many definitions and conceptions; it depends on the writer and the issue being addressed. Like most concepts in the social sciences and the humanities, there is lack of consensus among scholars and even conflict experts on the precise definition of the word "conflict". Ourtask here is to be drawn into the intellectual acrobatics of $x$-raying the various definitions. Anioke (2002), defines conflict as a difference or disagreement of opinions, ideals or goals between parties, individuals or groups. In point of fact, conflict could be inter-personal or inter-group. Again, it could present itself in a single or multi-dimensional form. It can be violent or non-violent, latent or manifest.

Adesina (2009) says that conflict is the act of striking together, mutual interference of opposing or incompatible forces, ideas, interest context, discord.

Ufok (1987) and Iwok (1995) almost shared similar opinion in the meaning of conflict. They view conflict as a state of emotional stress in a person or group of persons arising from collision of different needs, methods of operation in a given situation. 


\section{M| Macrothink

Oftentimes, conflicts either overtly or covertly manifest themselves thereby enabling people to sense their existence.

Based on the above, one can deduce that conflict can occur with:

- $\quad$ An individual - This is known as intra-personal conflict

- $\quad$ Between two groups- This is known as inter-personal conflict

- $\quad$ Between or among groups of people, units, or departments, this is known as inter group or unit conflict.

- Between or among different organizations or nations, this is known as interorganizational or inter-national conflict.

Fujana (1997) states that "modern industrial conflicts seem inevitable since the domination of management is to maximize profit while labour's concern is to secure and maintain the highest level of wages with the best conditions of their service. In this process conflicts emerged between the social partners in an effort of each partner to obtain maximum benefits of the industry. He defines industrial conflict "as a breakdown in the standard mechanism of decision making which leads an individual or group to experience difficulty in selecting a mutually acceptable alternative.

He continues that industrial conflicts do arise within the rank and file of all the actors in the organization including all the constituents in the role set of individuals. Such conflicts are referred to as inter-personal. It also involves an organized group of individuals acting concertedly.

Conflicts in organization and industrial establishment can be disruptive, when the organizational goals are stressful to the health of the individual workers and employees.

In another word, industrial conflicts can be defined as the inability of members in a role set to reach an agreement on an issue concerned with the objective of interaction. There is hardly any gainsaying the fact that industrial conflicts are realities of any economic system where workers and management or employers interact.

Anugwom (1997) argues that conflict goes a long way in shaping the industrial relations system of any nation. Hence, in spite of their differences, both parties are committed to the continuation of their relationship (Fashoyin,2010)

Labour conflict seems to be more pronounced in public sector organizations especially at local government councils. Anugwom and Ukaegbu (1998) argue that public unions have substantial market power and are usually in a position to play a key role in the political process. It is this unique positioning that make them conflict prone. Most of the public sector organizational conflicts are personal - organizational in nature. According to Ferrel and Fraedrick (1994), this occurs when a worker's industrial philosophies and methods for reaching a desired goal differ from those of the organization or a group within the organization. For example, suppose a local government chairman has strong views against using the local government workers revenue collection, while the policy of the government is contrary. In this case, the chairman's philosophy conflicts directly with the workers (individuals) personal philosophy.

There has been an increasing desire for peace and tranquility in the local government system as well as the public service. This is in recognition that industrial harmony engenders economic growth and enhances national development. Admittedly conflict occurs in all human organizations including industries and public bureaucratic organizations. But scholars as well as well meaning citizens advocate the need to find solutions to conflicts and the essence of promoting industrial harmony. Underlying the 


\section{M| Macrothink

inevitability of conflict in industrial relations, Njoku (2000) writes that "one of the qualities of a good trade union leader is his ability to resolve conflicts and settle grievances without hullabaloo".

Today, the Marxist interpretation of the nature of relationship between the employers and the employees in industrial organization (especially in capitalist countries) appears not realistic and fashionable. For, in most developed nations both the employers and the employees have developed, through mutual cooperation, strategies for conflict resolution.

Kornblum and Smith (1988) observed that in capitalist societies there is no persuasive evidence that division between workers and capitalists has heightened class conflict.

In the United States of America, for instance, most of the existing trade unions are said to be conservative in nature. They maintain co-operative relationships with their employers and use state legislation and agreements to protect their interests and improve working conditions of their members (Eshleman and Cashion, 2003).

The need to develop industrial harmony in the Nigerian local government system is even more paramount now that the local government is central to rural development.. In Nigeria, the Government is the largest employer of labour. The government workers or public servants are expected to co-operate with the government in power and vice versa for the purpose of implementing policies geared towards economic growth, social progress, stability and overall national development (Njoku, 2002)

\section{Causes of Labour Conflict}

As the size of an organization or industry increases, more managers ares employed they come in with different types of attitude, management and leadership styles. Goals become more formal, departments become more specialized and potentials for conflict increases (Halimatu, 2002).

Conflict is so closely related to loss of peace, that is tempting to define peace as the opposite of conflicts. Ofuebe (2001) argues that conflict is as central to life as we know it. A life without conflict is no life at all. Therefore, conflict is not abnormal in an organization hence a peace achieved by eliminating conflict is the peace of the graveyard. In the public sector, the workers are always disenchanted with the government over its handling of workers' welfare and the general penury facing the nation. Supporting this view are writers like Obasemi (2004) Chukwuezi (1996), and Etiebet (1996). They have expressed lack of faith in the government and in the country's present leadership. Usman (2005) has identified as the almost total freeze on new employment, large scale retrenchment, chronic and serious shortage of food stuffs and all types of goods as well as the high rate of inflation and the consequent reduction in real value of wages, salaries and allowances coupled with the interplay and irregular payment of these, as not auguring well for workers. Anugwom (1997) sees the economic depression in the country as exposing workers to a high level of economic hardship which was not witnessed in the past. He further contends that the public sector workers have been faced by given economic realities and may have seen conflicts as a way of breaking loose from the shackles of economic deprivation.

In the local government system, there are several sources of conflicts ranging from political instability, poor financial base, incessant demand for increase in wages, fringe 


\section{M| Macrothink

benefits, regular payment of salaries, leadership problem and poor communication (Ugwu, 2000).

Writing on politically instability as one of the causes of conflict at the Local Government, Obasi, (1998) argues that the Nigerian political and economic system for a long time have been characterized by an unstable political climate and economic recession consequent upon this high rate of instability in the political sub-system, local governments have experienced a lot of changes that are generating conflicts between policy makers and the workers.There has been series of petition writing, court litigation and demonstration by chairmen and councilors of local government over their tenure of office. In June 2002, most of the state governors including Enugu state dissolved their Local Government Executive and Legislative Councils and replaced them with appointed members to function as "Transitional to Executive" pending the time Local Government elections were held. There have also been conflicts over the interpretation of the relevant provisions of the 1999 constitution and the local government laws. Some examples of states where there have been conflicts in the Local Government include Enugu, Anambra, Ebonyi, Imo, River states to mention but a few (Ugwu, 2000). Specifically, some local governments, where there have been conflicts include Ohaozara and Abakaliki Local governments in Ebonyi State, Udi, Enugu south and Igbo -Etiti Local Government in Enugu State (Ugwu, 2000).

Other sources of conflict in the local government include:

\section{Poor Financial Base}

This is another source of conflicts in the local government. This is true and imperative, because it is inevitable to have and experience discrepancy between the wishes and fulfillment of workers in an environment of scarcity, which implies that the desires of the parties (workers and management) are more or less unlimited, while the means of satisfaction are limited. Today the regular story is "zero" allocation which in no small measure has impaired payment of workers salaries, fringe benefits and provision of social services by the local government.

\section{Lack of Communication}

Ugwu (2000) contends that lack of communication over issues and absence of effective organizational frameworks to handle grievance make workers feel despondent and aggrieved. This can bring about mistrust, misinformation and crisis.

\section{Payment of salary and other Workers' Benefits}

There is no gainsaying that in many local governments across the country today are owing their workers salary areas ranging from six to twenty-five months. Ezeja (2002) contends that local government workers in Enugu State are being owed areas of salaries between seven to twenty five months.

As at May, 2010, N15.3 billion was being owed local government workers as salary arrears nation wide (Ebo, 2010)

Watson (1987) postulates that the most fundamental reason why conflicts arise in employment situation is that the employers are 'using' employees for various purposes of their own whilst the employees in turn though from a weaker point or position are 'using' their employment for their own various purposes. 


\section{M| Macrothink

In most countries the right to work is seen as freedom for individuals to earn a living by work freely entered into. Wetlaufer (2001) and Johnson (1993), argue that the states contribution should be to create a climate under which individuals are able to exercise such a freedom. The work environment should not be a battle ground where the employee and employer should see each other as enemies. The two should rather see themselves as partners in progress and thus management have to ensure that use of participatory approach to decision making reigns supreme (Lya, 1987). Supporting this view Nwachukwu (1988) identified three major organizational leadership styles, namely autocratic, Laissez - faire, and democratic. He favours the democratic leader. The leader gets members involved in decision making. While the autocratic leadership is synonymous to conflict.

External sources of labour conflicts in work places include government industrial economy legislation, their ambiguous element which result in widespread inter/intra disputes, other issues are the National economic mismanagement, general pattern of distribution of wealth and power in the society (Otobo, 1992) He further states that some of these external factors/sources of conflict are not supposed to directly instigate labour conflict, but they may influence actual expectation substantially determined by the nature of work as demands and having an influence on the intensity of conflicts and the whole process of the conflict of industrial relations.

However, events in the middle and late 1980s in Nigeria showed that amidst the serious consequences of state economic Structural Adjustment Programme and the annulment of the June 12th 1993 presidential election, veteran industrial unions such as National Union of Petroleum Energy and Natural Gas (NUPENG), Nigerian Union of Local Government Employees (NULGE) and the Nigerian Labour Congress (NLC) attempted to crumble the social and economic activities of the country.

Mitroff (1994), identifies some of the factors that could lead to labour conflict in the public sector and industries. These are itemized under two broad headings - internal and external causes. The internal causes include, style of management, that is to say uncompromising, autocratic, non-participatory employer. These heighten labour conflicts. The social consciousness of the workers is yet another factor.

Warmer (2004) supports this opinion. He adds that when the management is provided with all the necessary welfare amenities, while the lower ranking workers are not considered for even the barest facilities, that conflict could readily ensue. Mitroff (1994) also identifies irregular or non-payment of salaries, wages and incentives as other internal factors that could lead to labour conflict. Others are improper termination of appointment, conditions of employment that does not make for average living, poor guidelines for motivation and promotions in the organization, cumbersome grievance and dispute procedure, breach of collective agreement and anti-union actions. Holt, Havid and Brau (2004) support this view by saying "when employers ignorantly refuse or grant recognition to workers union under trade group or victimize them, it could lead to labour conflict".

The external causes of labour conflict contends Mitroff (1994) ranges from government poor economic and industrial policies, when labour laws contain provisions that do not protect adequately the interest of workers and finally economic mismanagement and unequal distribution of power in the society.

The International Labour Report (1998) further states that labour conflicts can be caused as a result of conflict of interest, generally described as conflicts of interest or economic 
disputes, they generally correspond to what is also described as collective labour disputes, this relates to the establishment of new term and condition of employment for the general workers concerned.

Grievance and disputes, are other forms of conflicts argues Barret, Covali and Domnic (2005). They are usually called "conflict of rights or legal disputes". They include workers in the same organization and correspond largely to what in certain countries are called individual disputes. Such disputes usually arise from day to day relation in the organization against acts of the management, especially in the case of dismissal of staff if seen as wrongfully, illegal and unsatisfactory. This form of disputes abounds in Nigeria. For instance in Enugu State, more than five thousand workers were disengaged from the Public Bureaucracy in November, 1999 (Chukwuemeka, 2004).

Barret, Covali and Domnic (2005) further enunciated the primary and underlying causes of disaffection in the industrial situation as advanced by labour unions, workers representatives, industrial psychologists, sociologists, management consultants, employers and others include:
a. Agitation from laudable desire by workers for a better living
b. Protest against low wages, long hours of work and improper working conditions.
c. Desire on the part of the workers for a voice in the determination of the conditions under which they labour and a revolt against suppression by the organization.
d. A desire for better working conditions
e. Misunderstanding and prejudices as agreed by the employers and employees.
f. Misinformation in Newspapers that can cause disaffection among the populace thereby leading to industrial unrest.
g. Lack of attention to sickness and accidents and the difficulty and delay in accident victims, security compensation for victims under the enabling labour laws.

h. Suppression of freedom of speech and the right to assembly.

As regards to labour laws, Nigeria has got a number of labour laws as enunciated by Anarado (1999).

The Nigerian labour Laws are in five groupings:

a. law relating to conditions of employment

b. Trade Union matters

c. Laws on industrial relations

d. Laws on welfare, wages and safety of workers at work and

e. Miscellaneous labour laws.

While, the laws bordering on industrial relations are:

a. The Trade Dispute Decree No.7 of 1976

b. Trade Disputes (Essential Services) Decrees No. 23 of 1976

c. Trade Disputes (Amendment) Decree No. 54 of 1977

d. Trade disputes (Amendment) Decree No. 39 of 1988

e. $\quad$ Trade disputes (Amendment) No. 2 Decree NO. 57 of 1988 and

f. $\quad$ Trade disputes (Amendment) Decree No. 47 of 1992.

\section{Theories of Industrial Conflict}

It is generally perceived that the factors that gave rise to trade unionism may not necessarily be the same factors underlying industrial conflicts, some of the theoretical 


\section{M| Macrothink

explanations for the phenomenon of labour unionism are also used in seeking to explain industrial conflicts. As a result, such sociological orientations as the conflict, the functionalist, the neo-classical economic or prosperity, and the industrialization theses (Chamberlain and Caller, 1965, Comfielld, 1986),

But of all these theories, the conflict and neo classical economic view points seem more amenable to the explanation of contemporary industrial conflicts.

Anugwom (1997), Dhrendorf (1976) see conflict not only as necessary but also as functional to the society and industrial enterprise. Dhrendorf further sees industrial conflict as a basic factor underlying societal dynamics. The industrialization paradigm sees the rise of industrialization as to create a scenario where all participants are interested in gain maximization. When this happens, there is bound to be conflict which results from the struggle. Similar to the industrialization thesis of the conflict theory of industrial conflict. The central argument in that theory is that the conflict between management and labour results from the fact that they have conflicting and contradicting interests. These interests are not only inherent in each group but are also irreconcilable with that of the opposing group. Hence the relationship between the two groups is confliction in nature.

However, there are other labour conflict theories which are either management, technology or Marxist based.

Michael (1997) a scholar of the human relations school confirms that the theory has its origin from the theories experimented in an industry (Hawthorne studies) of which the main proponent is Elton Mayo. The central thesis of the theory is based on the importance of informal relationship, good communication and supervision in the work place as sources of industrial harmony and peace.

One of the important findings of the Hawthorne studies is that informal social groups play a crucial role in work place. Mayo cited in Michael (1997), Cornfield (2011) stated how an information group can frustrate the efforts of management. He summarizes that he absence of proper communication within the group may be a cause of frustration and dissatisfaction that ultimately may be a cause of labour conflict.

Similarly, the neo human relations school added that workers seek for well defined satisfaction from their employment and emphasize that these factors of satisfaction may not be mainly monetary rewards.

Therefore, the human relation school argues that in any organization, it is no doubt desirable to improve communication and increase freedom of workers to have their decision in the work places to enable them feel part of the organization. Accordingly, this reduces conflict in work places.

The Marxist School of Thought as expressed by Miles (1992), states that industrial relations occur within dynamic conflict situation. Such conflict situation viewed as a product of labour market in which the workers sell their labour on one hand and the buyers of labour power who own the means of production purchase the labour power (for them the cost of labour power is an implicit factor in the cost of production on the other hand). Thus he states that:

These two interests are irreconcilable. They are engaged in perpetual conflict on the distribution

of revenue. It might be stated that the interest

have a common purpose in increasing total revenue, but the conflict over distributions is a sure lessened by 


\section{M| Macrothink

this for the actual distribution of additional increment

of revenue determined by the power situation. Employees with no

power may get nothing. There is

no automatic distribution based on sense of fairness and equality, shares have to be fought for sometimes

bitterly (Miles, 1992)

Thus, the concept of alienation also display a crucial role in Marxist's thinking of industrial conflict. Alienation arises from the fact that in the capitalist mode of social relation, labour is sold, and it is bought by the capitalists and used to satisfy his (capitalist's) needs rather than the workers. So the worker is estranged from the wealth he creates and in turn violates the essential nature of man. Marx wrote that the alien character of the worker under which capitalism emerges clearly is the fact that as soon as no physical or other compulsion exist labour is seen like plague.

Alienation is vividly seen in modern industrial labour. Thus in division of labour which is seen by the Marx cited in Miles (1992) as a means of promoting wealth for the capitalist by restricting even more clearly the freedom of the worker and the proceeds of his labour power. Also the factory system of production which is viewed the most complete method of domination of the worker by the capitalist for he can control every activity of labour.

He concludes that alienation cannot be simply overcome by increasing salaries and wages but only with the overthrow of the capitalist system when labour will cease to be treated as a commodity.

Another theory of labour conflict is technology based theory postulated by Kuhn. Kuhn experimented in the Tyre Rubber Industry and the electrical industry where he discovered that workers in Tyre industry tended to press for more demand than those in the electrical equipment industry (Leonard 1989).

He suggested that technologies with the following characteristics are more conducive fractional bargaining.

He further stated that the process subject a large proportion of workers to continued changes in work method, standard materials as well as the individually paid job. Secondly, the condition that permits interaction between the workers in the same task group e.g. the case of food processing and the construction industry.

\section{Objectives of the Study}

The general objective of this study is to examine the indices of labour conflict in Nigerian local government system with emphasis in Enugu State. The specific objectives of the study are therefore:

4. To find out the raison d' et re for management- labour conflict in Nigeria Local Government system, especially Enugu State.

5. To examine the relationship between the nature of management leadership approach and the degree of labour conflict.

6. To examine the relationship between meaningful workers participation in the local government administration or lack of it and the increasing management labour conflict.

7. To determine the extent to which "zero" allocation contributed to the endemic labour unrest in the Nigerian local Government system especially in Enugu State. 


\section{MIMnstitute "'

\section{Theoretical Framework}

This study was anchored on the general systems approach. Systems analysis is a part of the behaviouralist movement which had been growing in various America universities, starting with the University of Chicago - as a reaction to the traditionalist approach. It was in this search for theory- building that scholars like David Easton, Ludwig Von Bertanaffy, a Biologist, Morton, Kaplan, Karl Deutsch, Stanley Holfmann, Charles Mcclelland to quote a few developed the system model (Varma, 1975). System theory was popularized in political science by David Easton (a Political Scientist). In recent times, the systems theory has become as increasingly useful framework for thinking about organizations and managerial functions. Organizations, like the local government are open systems with certain boundaries that differentiate it from other systems. It must constantly receive multitude of inputs from its external environment (people, form, input, information) in order to achieve its objectives.

Therefore, to survive and prosper, an organization must be productive. It must return to its external environment certain outputs in order to justify its existence and get the support it needs.

The system theory is an analytical tool which enables theorists and researchers to study key elements of organizations in terms of their interaction with one another and with their external environment. Social systems are always open systems with inputs, outputs, and conversion process. In relation to an organization, inputs refer to people, materials, information and finance. These inputs are organized and activated so as to convert human skills and raw materials into products, services and other outputs which are discharged into the environment.

It is important to state here that our research which is focussed on "Labour Conflict and Management in Nigerian Local Government System" is of vital importance in the study of the relationship between labour conflict and management. The local government is an organization, a system within a larger system of its environment. The workers, the subunits and labour union within the organization constitute the internal environment of the organization.

The system theory as a framework for the study of labour conflict and management in Nigerian Local Government system enables us to understand and explain how environmental factors (like conflict) affect the internal working of the local government system and how this could bring about the collapse of the system.

Fig 1

The System Approach to Organization

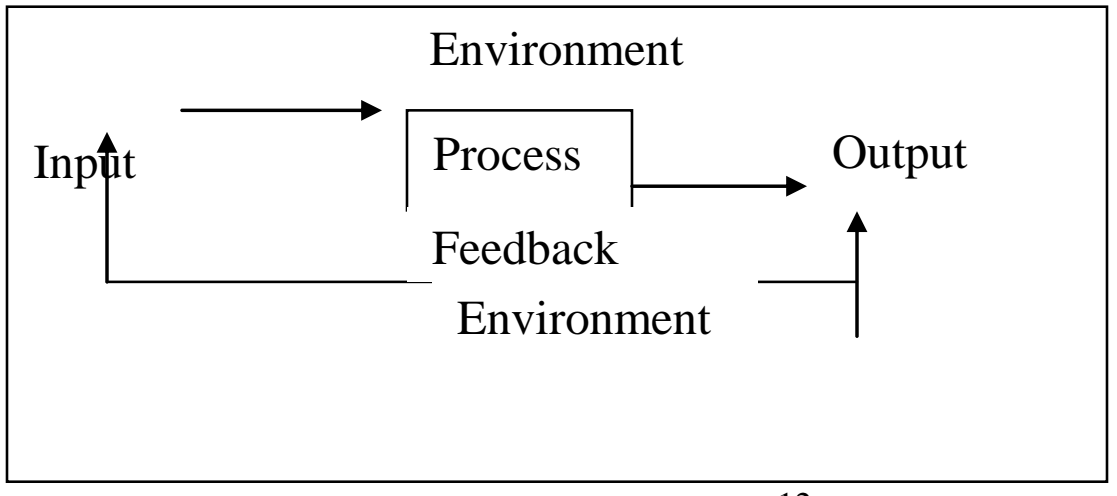

12 
The system model is not only necessary but indispensable in our examination of the Nigerian local government system and labour conflict and management.

This theory precipitates the notion that:

a. The Local Government is an organization (A system) that has a number of political functions to perform to the people. Therefore, conflicts constitute dysfunction to the system and therefore does not encourage system survival as enunciated by functional theorists.

b. That the major emphasis is on system survival, goal attainment, system maintenance. There are basic input, output and feedback functions of a system and these functions cannot be performed by the system when it is reddened by labour conflict.

c. That effective communication is seen as essential within the system. From the literature review, poor communication in the system was identified as one of the causes of labour conflict in the local government system.

\section{Methodology}

\section{Research Methods}

The descriptive research method was used in carrying out the study. This method was chosen because; it is the method that best interprets labour- management conflict, without loss of facts. Specifically, two descriptive research methods were used namely survey research and case study of Enugu State of Nigeria.

\section{Data Collection Techniques}

Questionnaire, oral interview and personal observation were used as instrument for data collection. In this case the researcher fashioned an interview schedule which was entitled "instrument I - interview guide, it contained the structured questions. The questions covered essential issues in management labour relations and general local government administration in Nigeria. The instrument was used mainly to elicit information from local government practitioners and labour unionists. While instrument 2 , questionnaire was be made up of structured questions, multiple choice questions, open ended questions and likert 5 - point scale attitudinal measurement questions. The questionnaire were administered to the respondents.

a. The structured questions in instrument 2 gave respondents answers to choose from. The questions were drawn from the hypotheses and objectives of the study.

\section{Target Population:}

The population of the study constituted all the workers in Enugu State Local Government System.

\section{Sample Size}

Yamene formula was used to chose sample size from the population of $10,100 \mathrm{In}$ view of this, the researcher will choose a sample size by using Yamani Formula.

$$
\mathrm{n}=\frac{\mathrm{N}}{1+\left(\mathrm{Ne}^{2}\right)}
$$


$\begin{array}{cl}\text { where } \mathrm{n} & =\text { Sample Size } \\ \mathrm{N} & =\text { population Size } \\ \mathrm{e} & =\text { error limit }\end{array}$

Using the population of workers in the seventeen local government councils of Enugu State $(10,100)$

With $\mathrm{n}$ representing the sample size

$\mathrm{N}$ representing the population

e representing the margin of error

$$
\begin{array}{lll}
\mathrm{N} & = & 10,100 \\
\mathrm{e} & = & (0.05) \text { or }(0.0025) \\
\mathrm{n} & =\frac{10,100}{1+(10,100 \times .0025)} \\
& \mathrm{n} \quad=401 \text { workers }
\end{array}
$$

\section{Test of Hypothesis}

\section{Hypothesis}

Ho: There is no correlation between trade dispute and strike

Ho1: There is positive correlation between trade dispute and strike

To test thus hypothesis correlation coefficient (r) test was adopted

$$
\sqrt{\sqrt{\sum(\mathrm{x}-\overline{\mathrm{x}})^{2} \sum(\mathrm{y}-\overline{\mathrm{y}})^{2}}} \quad \text { or } \frac{\mathrm{N} \Sigma \mathrm{XY}-\left(\sum \mathrm{X}\right)\left(\sum \mathrm{Y}\right)}{\left.\mathrm{N} \Sigma \overline{\mathrm{X}}^{2}-\sum \overline{\mathrm{x}}\right)\left(\mathrm{N} \Sigma \overline{\mathrm{Y}}^{2}\right)}
$$

or $\mathrm{r} \quad \sum \mathrm{xy}$

$$
\sqrt{\sum \overline{\mathrm{x}}^{2} \sum \overline{\mathrm{y}}^{2}}
$$

Where $X=$ Independent variable

$$
\begin{aligned}
& \bar{Y}=\text { Dependent variable } \\
& \bar{X}=\text { Mean of the independent variable } \\
& \bar{Y}=\text { Mean of the dependent variable }
\end{aligned}
$$

\begin{tabular}{|l|l|l|}
\hline Year & No. Trade Dispute X & No of strike Y \\
\hline 1998 & 6 & 2 \\
\hline 1999 & 8 & 2 \\
\hline 2000 & 10 & 1 \\
\hline 2001 & 7 & 1 \\
\hline 2002 & 10 & 1 \\
\hline Total & 35 & 7 \\
\hline
\end{tabular}

Sources: NULGE, Enugu North L.G.A Chapter office

Table 4.2.2- Correlation Coefficient table

\begin{tabular}{|l|l|l|l|l|l|l|}
\hline $\mathrm{X}$ & $\mathrm{Y}$ & $\mathrm{x}-\overline{\mathrm{x}}$ & $\mathrm{y}-\overline{\mathrm{y}}$ & $(\mathrm{x}-\overline{\mathrm{x}})^{2}$ & $(\mathrm{y}-\overline{\mathrm{y}})^{2}$ & $(\mathrm{x}-\overline{\mathrm{x}})(\mathrm{y}-\overline{\mathrm{y}})$ \\
\hline 6 & 2 & -2.2 & 0.6 & 4.84 & 0.36 & 1.32 \\
\hline 8 & 2 & -0.2 & 0.6 & 0.44 & 0.36 & 0.12 \\
\hline 10 & 1 & 1.8 & -0.4 & 3.24 & 0.16 & 0.72 \\
\hline 7 & 1 & -1.2 & -0.4 & 1.44 & 0.16 & 0.48 \\
\hline 10 & 1 & 1.8 & -0.4 & 3.24 & 0.16 & 0.72 \\
\hline
\end{tabular}




\begin{tabular}{|l|l|l|l|l|l|l|}
\hline 41 & 7 & 0 & 0 & 13.2 & 1.2 & 3.36 \\
\hline
\end{tabular}

$$
\begin{aligned}
& \frac{\bar{X}=8.2}{\mathrm{Y}=1.4} \\
& \mathrm{r} \frac{\sum \sum(\mathrm{x}-\overline{\mathrm{x}}) \sum(\mathrm{y}-\overline{\mathrm{y}})}{\sqrt{\sum(\mathrm{x}-\overline{\mathrm{x}})^{2} \sum(\mathrm{y}-\overline{\mathrm{y}})^{2}}} \\
& \mathrm{r} \quad=\frac{3.36}{(13.2)(1.2)} \\
& \mathrm{r} \quad=\frac{336}{(3.63)(1-09)} \\
& \mathrm{r} \quad=\quad \frac{3.36}{3.96} \\
& \mathrm{r} \quad=\quad+0.84
\end{aligned}
$$

From the decision 0.84 indicates that there is high relationship between trade dispute and strike.

\section{Hypothesis two:}

Ho : Labour conflict is not independent of leadership style

H1: Labour conflict is independent of leadership style.

Hypothesis two was tested using chi-square $\left(\mathrm{x}^{2}\right)$.

Chi-square $\left(\mathrm{x}^{2}\right)=\frac{(0-\mathrm{E})^{2}}{\mathrm{E}} ; \mathrm{E}=\underline{\mathrm{R}}_{1} \frac{\mathrm{x} \mathrm{C}_{1}}{\mathrm{n}}$

$0=$ Observation Frequency

$\mathrm{E} \quad=\quad$ Expected frequency

$\mathrm{R}_{1}=$ Row 1

$\mathrm{C}=$ Column 1

$\mathrm{n}=$ Grand total of the group

$\mathrm{X}^{2}=$ chi-square

\section{Decision rule:}

In the application of the chi-square $\left(\mathrm{x}^{2}\right)$ test, the generally expected criteria for decision are stated below:

Accept Ho (null hypothesis) if $\mathrm{T} . \mathrm{V} \geq \mathrm{C} . \mathrm{V}$

Rejected h0 if T.V < C.V

$\begin{array}{cll}\text { Where C.V } & = & \text { Calculated value of chi }- \text { square test }\left(\mathrm{x}^{2}\right) \\ \mathrm{T} . \mathrm{V} & = & \text { Table/critical value or critical ratio. }\end{array}$

Table 4.1.16 was analyzed - How many times has the style of leadership led to conflict in your local government between 1998-2002?

To solve for expected frequency $=$

\section{1-20 times:}

$\begin{array}{lllll}\frac{105}{360} \times & 228 & =\frac{23940}{360} & =66.5 \\ \underline{240} \times & 228 & =\underline{54720} & =152.0\end{array}$




$\frac{15}{360} \times 228=\frac{3420}{360}=9.5$

\section{1 times and above}

$\begin{array}{lrrrr}\frac{105}{360} & \times & 132=\frac{12860}{360} & =38.5 \\ \frac{240}{360} & \times & 132=\frac{31680}{360} & =88.0 \\ \frac{15}{360} & \times & 132=\frac{1980}{360} & =5.5\end{array}$

Chi-square test of independence

For observed and expected frequencies

\begin{tabular}{|l|l|l|l|l|}
\hline 0 & $\mathrm{E}$ & $0-\mathrm{E}$ & $(0-\mathrm{E})^{2}$ & $\frac{(0-\mathrm{E})^{2}}{\mathrm{E}}$ \\
\hline 90 & 66.5 & 23.5 & 552.25 & 8.30 \\
\hline 130 & 152.0 & -22.0 & 485 & 3.18 \\
\hline 8 & 9.5 & -1.5 & 2.25 & 0.23 \\
\hline 15 & 38.5 & -23.5 & 552.25 & 14.34 \\
\hline 110 & 88.0 & 22.0 & 484 & 5.5 \\
\hline 7 & 5.5 & 1.5 & 2.25 & 0.40 \\
\hline 360 & 360 & 0 & 2077 & 31.95 \\
\hline
\end{tabular}

Source Analyzed from table 4.1.16

Calculated value $=\Sigma(\underline{(0-\mathrm{E})} \quad=31.95$

$\mathrm{E}$

At 0.05 significance level

$\mathrm{df}=(\mathrm{r}-1) \quad(\mathrm{c}-1)$

where: $\mathrm{df}=$ Degree of freedom

$$
\begin{array}{rll}
\mathrm{r} & = & \text { Row number } \\
\mathrm{C} & = & \text { Column number } \\
\mathrm{Df} & = & (\mathrm{r}-1)(\mathrm{c}-1) \\
& = & (3-1)(3-1)=2 \times 2=4
\end{array}
$$

$\mathrm{T} . \mathrm{V}=9.488$ while calculated value $=31.95$

Decision: Since C.V is greater than T.V at 5\% significance level, we reject H0, which states that labour conflict is not independence of leadership style and accept $\mathrm{H}_{1}$ the alternative/researcher hypothesis which states that labour conflict is independent of leadership style. 


\section{Macrothink

\section{Findings}

The findings revealed that the organizational framework for management of conflict and grievances is poor. The problem is as a result of leadership ineffectiveness which according to the study had resulted to disputes and consequently to strike actions. Management scarcely bargains with staff in resolving conflict situations. Management does not always explain its reasons for taking a particular position in resolving conflicts.

The study further revealed that other factors that heightened labour conflict include low participation of employees in taking key decisions, especially matters affecting them.

The Local Government of Enugu State of Nigeria is believed to be poorly funded, This information was furnished by a key respondent Ugwuja (2010)According him the poor funding is peculiar to the following local governments: Enugu North, Igbo-Eze North, and Nsukka Local Government Areas.. The aforementioned local government areas were consistently on 'zero allocation', which the resultant effect was epileptic payment of salaries and allowances of workers.

Table - Relative ranking of the factors that induce labour conflict in Enugu State Local Government System

\begin{tabular}{|c|c|}
\hline Factors & Ranking based on respondents' opinion \\
\hline Funding & 240 our of 360 respondents said yes $=1^{\mathrm{st}}$ \\
\hline Leadership type/ ineffectiveness & $\begin{array}{l}132 \text { out of } 360 \text { respondents said it is } \\
\text { autocratic - ineffective } \quad=2^{\text {nd }}\end{array}$ \\
\hline $\begin{array}{l}\text { Low employees' participation in decision } \\
\text { making }\end{array}$ & $\begin{array}{l}109 \text { out of } 360 \text { respondents said that the } \\
\text { participation is not encouraging }=3^{\text {rd }}\end{array}$ \\
\hline
\end{tabular}

Source: Compiled by the researcher

The table above reveals that the ranking of the three latent factors that contribute to labour conflict but however not the manifest factors. Fundng ranked highest, followed by leadership ineffectiveness while low employees' participation in decision making ranked the least. The implication of the information in this table therefore, is that the Enugu State Local Government System should take cognizance of this relative ranking of the latent and manifest factors that induce labour conflict towards minimizing labour conflict. 


\section{M| Macrothink

\section{Recommendations}

Based on the findings the following recommendations are considered desirable:

A democratic leadership style should be imbibed in Enugu State Local Government Councils to ensure congenial work relationship, the reign of democracy, as a style would ensure reduction of labour conflict.

In spite of the fact that funding was not identified as a major problem that led to labour conflict, funding of the Local government in Nigeria should be strengthened.

Management and staff of the local government should strive to see labour conflict as a process to change and thus try to resolve it in such a way that both parties are winners. Labour conflict should be resolved through the instrumentality of collective bargaining, which involves negotiation, dialogue, or mediation by a third party or through statutory framework which involves Trade Dispute ACT No.7 of 1976 as amended in 1977.

Both political office holders and career officials should respect the laws and guidelines governing administrative conduct and practices in order to reduce the incidence of labour conflicts within the system.

\section{Conclusion}

Conflict is not a negative pathological condition characterized only by lack of cooperation, hostility and struggle; rather it is a process which signals a need for change.

\section{References}

Akereke, A. (2010), "The Environment of Industrial Relations: Participants Influencing Factors", Nigerian Journal of Economics And Social Studies 17(3) 34-40

Anarado A (1999) Managing Labour conflict in a depressed economy, American Journal of Social Sciences, 6(2) 22-32

Anugwom, E. (1997) “The Public Sector And Industrial Conflict In Nigeria: Facts And Issues" , Nigeria Journal of Public Administration and Local Government . 8 (1) 45-48

Anugwom, E. and Ukaegbu, C.C. (1998), "Economic Conditions and Industrial Conflicts In Nigeria: A Comparative Study Of Pre- SAP And SAP Periods (1981-92)", Nigerian Journal Of Public Administration And Local Government, 9(1) 30-39

Aka,E (2009) The evil consequences of labour conflict, Asian Labour Review, 4 (4) $12-23$ 
Akpala, A. (1984),_Critical History of Nigerian Industrial Relations

(1937- 61), Enugu: Provision Publishing Co.

Anioke, U (2002) Local Government and Conflict, Journal of Policy and Development

Studies, 3(2) 45-47

Adesina, H (2009) Fundamentals of Management, Lagos: Mangroove Books

Barret W, Covali B and Domnic S. (2005) Industrial Relations and Worker Society,

Aspect of Interaction: London: Macmillan

Chikelue, O. (2001) "The Individual and Conflict in Society" in

Dynamics of Social Studies C. Ofuebe (ed), Enugu: New

Generation Books

Chukwu J (2008) The Challenges of labour conflict to an emerging economy,

International Journal of Business management, 2(4) 25-35

Chukwuemeka, E (2011) Labour Conflict in Enugu State Bureaucracy, African

Development Review, 1(2) 100-113

Chukwuezi, U (1996) Introduction to Sociology, Enugu: JTC Publishers

Chamberlain, N. and Culler D. (1995),_The Labour Sector, New

York: McGraw Hill

Cornfield, D. (2011) “Declining Union Membership In Post World

War 11 Era: The United Furniture Workers Of America 1939-

1982”, American Journal Of Sociology 9 (5) 20-30

Donkor, J (2010) Why workers do not perform, African Journal of Management

Sciences, 2(2) 40-48

Domnic, U (2005) Managing Men at work, New York: McGraw Hills

Dhrendorf, R. (1976), Class and Class conflicts in Industrial Society, London: Routledge and Kegan Paul.

Demachi., V.G. (2005), Industrial Relations, A Development Dilemma, Enugu: Fourth Dimension Publishers.

Ebo, N (1998) Principles of conflict management, Enugu: HRV Publishers

Eshleman, J.S and Cashion, B.G. (2003), Sociology: An Introduction,

Boston: Little Brown and Co

Ejiofor, P. (1989), Foundation of Business Administration, Onitsha:

African FEP publishers

Eze. L. (2007) Management of Industrial Relations in Nigeria, Enugu 


\section{Hope-Rising Publications}

Ezema, E (2007) An Introduction of Sociology, Enugu: HRV Publishers

Etiebet. M (1996) The Role of Leadership in the management of labour conflict

Nigerian Management Review, 3(3) 40-50

Fashoyin, T. (2010), "Nigerian Labour and The Military: towards exclusion" Labour, capital and society 3 (1) 14-18

Frederick J (1994) Industrial Relations: A contemporary perspective,

South Africa:W \& G Publishers

Fujana W (1997), Industrial Relations in Nigeria, Ikeja: Longman.

Halimatu . O (2002) Labour Conflict and Management in Tabaco Industries Journal of Management and Social Sciences, 2(5) 30-39

Holt, S, Havid T and Brau K (2004) Management Principles, New York:

Grona Publishers

Imaga, E. U. L. (1990), Industrial Democracy in the third World; A Study of Nigeria and India, New Delhi: south Asian publishers.

Iwok G (1995) Managing Grievance in a conflict situation, Journal of Management, 2(2) 20-28

Johson, C (1993), "Comparative Capitalism: the Japanese Difference"

California Management Review, vol. 35. No. 4 (Summer).

Administration in Nigeria: Current issue and Future Challenges Lagos: Mangrove Publishers.

Kornblum, W and Smith, C.D. (1988), Sociology in a Changing

World, New York: Holt Inc.

Lyn, T. (1987), "Labour participation in Corporate Policy-Making \

Decisions: West Germany's Experience with Codetermination", International Journal of Business 60 (4) 60-70

Leonard, O (1989) Introduction to Psychology, Lagos: Vinez Publishers Ludwig, Von Bertanalffy (1956), "General System Theory", General

Systems Year Book of General Systems Theory, Ann Arbor (ed) vol. 1.

Miles, R. (1992), "Causes of Faulure in Network Organization”, California Management Review 34..( 4 ) 29-31 


\section{M| Macrothink

Mitroff, L.(1994) “Crisis Management and Environmentalism - A

Natural Fit", California Management Review 36. ( 2 ) 45-50

Michael, J. (1997), Industrial Relations, London: Groom Helm

Nwabuzor, A. M. (1990), Business- Government Relations in Nigeria

Ibadan: Macmillan Nig. Pub. Co..

Nwachukwu, C.C. (1988), Management; Theory and Practice; Onitsha:

African FEP Publishers.

Njoku A. O. (2000), "Dialogue the Tool for Government - Labour

Functional Relationship" in contemporary Issues in Local Government Administration and Rural Development Umebali E. et. al. (eds) Enugu: Computer Edge Publishers.

Otobo, D. (1992), Labour Relations in Nigeria vol. 1, Oxford: Mathouse Press Ltd.

Obasi, I. N. (1999), Research Methods in Political Science Enugu: Academic Pub. Co.

Obasemi, R (2004) Sources of Conflict in the public sector organizations, Lagos: Mangroove Publishers

Ufok.T (1987) Management: A Concise Approach, Benin City: Ethiope Publishers

Ugwu, S.C. (2000), Issues in Local Government and Urban Administration in Nigeria: Enugu Echisi Publishing Co.

Ugo I (2011) The Challenges of zero allocation in Nigeria local government system Journal of Policy and Development Studies, 4(2) 100-108

Usman, B.Y, (2005), "Understanding and Resolving Current Economic Crisis in Nigeria Nigeria, African Development Review 1(2) 35-42

Varma, S.P. (1975), Modern Political Theory, A Critical Survey, Junipur: Vani Educational Books.

Walker, R.T. (1975) Workers Participation In Management Concepts And Reality: London: Alan And Urwin

Wetlaufer, S. (2001) “Common Sense and Conflict”, Havard Business Review 10 (1) 2 27-35

Warmer T. (2001) Sociology, Work and Industry, London: Routledge and Kogan Paul 